4

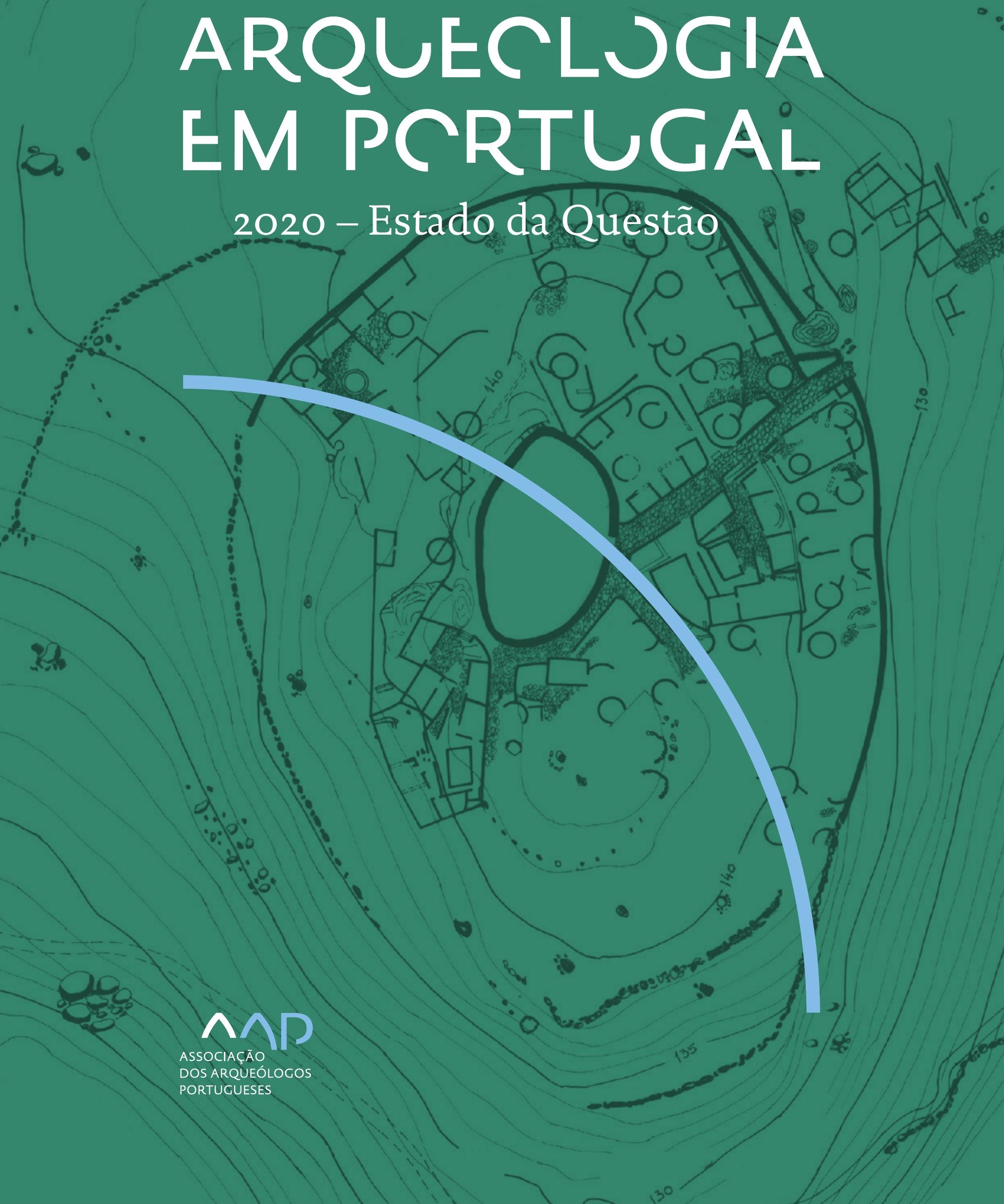


Coordenação editorial: José Morais Arnaud, César Neves e Andrea Martins Design gráfico: Flatland Design

AAP - ISBN: 978-972-9451-89-8

CITCEM - ISBN: 978-989-8970-25-1

Associação dos Arqueólogos Portugueses e CITCEM

Lisboa, 2020

O conteúdo dos artigos é da inteira responsabilidade dos autores. Sendo assim a Associação dos Arqueólogos Portugueses declina qualquer responsabilidade por eventuais equívocos ou questões de ordem ética e legal.

Desenho de capa:

Planta do castro de Monte Mozinho (Museu Municipal de Penafiel).

\section{$\hat{\wedge} \mathrm{P}$}

DOS ARQUEÓLOGOS PORTUGUESES

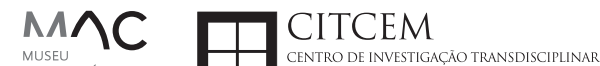
MUSEU
ARQUELLÓGICO
DO CARMO
U.PORTO

FLUP FACULDADE DE LETRAS
UNIVERSIDADE DO PORTO

Apoio

EC para a Ciência 


\section{Índice}

15 Prefácio

José Morais Arnaud

\section{Historiografia e Teoria}

17 Território, comunidade, memória e emoção: a contribuição da história da arqueologia (algumas primeiras e breves reflexões)

Ana Cristina Martins

25 Como descolonizar a arqueologia portuguesa?

Rui Gomes Coelho

41 Arqueologia e Modernidade: uma revisitação pessoal e breve de alguns aspetos da obra homónima de Julian Thomas de 2004

Vítor Oliveira Jorge

57 Dados para a História das Mulheres na Arqueologia portuguesa, dos finais do século XIX aos inícios do século XX: números, nomes e tabelas

Filipa Dimas / Mariana Diniz

73 Retractos da arqueologia portuguesa na imprensa: (in)visibilidades no feminino

Catarina Costeira / Elsa Luís

85 Arqueologia e Arqueólogos no Norte de Portugal Jacinta Bugalhão

101 Vieira Guimarães (1864-1939) e a arqueologia em Tomar: uma abordagem sobre o território e as gentes

João Amendoeira Peixoto / Ana Cristina Martins

115 Os memoráveis? A arqueologia algarvia na imprensa nacional e regional na presente centúria (2001-2019): características, visões do(s) passado(s) e a arqueologia

enquanto marca

Frederico Agosto / João Silva

129 A Evolução da Arqueologia Urbana e a Valorização Patrimonial no Barlavento Algarvio: Os casos de Portimão e Silves

Artur Mateus / Diogo Varandas / Rafael Boavida

\section{Gestão, Valorização e Salvaguarda do Património}

145 O Caderno Reivindicativo e as condições de trabalho em Arqueologia Miguel Rocha / Liliana Matias Carvalho / Regis Barbosa / Mauro Correia / Sara Simões / Jacinta Bugalhão / Sara Brito / Liliana Veríssimo Carvalho / Richard Peace / Pedro Peça / Cézer Santos

155 Os Estudos de Impacte Patrimonial como elemento para uma estratégia sustentável de minimização de impactes no âmbito de reconversões agrícolas Tiago do Pereiro

165 Salvaguarda de Património arqueológico em operações florestais: gestão e sensibilização Filipa Bragança / Gertrudes Zambujo / Sandra Lourenço / Belém Paiva / Carlos Banha / Frederico Tatá Regala / Helena Moura / Jacinta Bugalhão / João Marques / José Correia / Pedro Faria / Samuel Melro

179 Os valores do Património: uma investigação sobre os Sítios Pré-históricos de Arte Rupestre do Vale do Rio Côa e de Siega Verde José Paulo Francisco 
189 Conjugando recursos arqueológicos e naturais para potenciar as visitas ao Geoparque Litoral de Viana do Castelo (Noroeste de Portugal)

Hugo A. Sampaio / Ana M.S. Bettencourt / Susana Marinho / Ricardo Carvalhido

203 Áreas de Potencial Arqueológico na Região do Médio Tejo: Modelo Espacial Preditivo Rita Ferreira Anastácio / Ana Filipa Martins / Luiz Oosterbeek

223 Património Arqueológico e Gestão Territorial: O contributo da Arqueologia para a revisão do PDM de Avis

Ana Cristina Ribeiro

237 A coleção arqueológica do extinto Museu Municipal do Porto - Origens, Percursos e Estudos

Sónia Couto

251 Valpaços - uma nova carta arqueológica

Pedro Pereira / Maria de Fátima Casares Machado

263 Arqueologia na Cidade de Peniche

Adriano Constantino / Luís Rendeiro

273 Arqueologia Urbana: a cidade de Lagos como caso de Estudo Cátia Neto

285 Estratégias de promoção do património cultural subaquático nos Açores. O caso da ilha do Faial

José Luís Neto / José Bettencourt / Luís Borges / Pedro Parreira

297 Carta Arqueológica da Cidade Velha: Uma primeira abordagem

Jaylson Monteiro / Nireide Tavares / Sara da Veiga / Claudino Ramos / Edson Brito /

Carlos Carvalho / Francisco Moreira / Adalberto Tavares

311 Antropologia Virtual: novas metodologias para a análise morfológica e funcional Ricardo Miguel Godinho / Célia Gonçalves

\section{Didáctica da Arqueologia}

327 Como os projetos de Arqueologia podem contribuir para uma comunidade culturalmente mais consciente Alexandra Figueiredo / Claúdio Monteiro / Adolfo Silveira / Ricardo Lopes

337 Educação Patrimonial - Um cidadão esclarecido é um cidadão ativo! Ana Paula Almeida

351 A aproximação da Arqueologia à sala de aula: um caso de estudo no $3^{\circ}$ ciclo do Ensino Básico Luís Serrão Gil

363 Arqueologia 3.o - Pensar e comunicar a Arqueologia para um futuro sustentável Mónica Rolo

377 “Conversa de Arqueólogos" - Divulgar a Arqueologia em tempos de Pandemia Diogo Teixeira Dias

389 Escola Profissional de Arqueologia: desafios e oportunidades Susana Nunes / Dulcineia Pinto / Júlia Silva / Ana Mascarenhas

399 Os Museus de Arqueologia e os Jovens: a oferta educativa para o público adolescente Beatriz Correia Barata / Leonor Medeiros

411 O museu universitário como mediador entre a ciência e a sociedade: o exemplo da secção de arqueologia no Museu de História Natural e da Ciência da Universidade do Porto (MHNC-UP)

Rita Gaspar 
421 Museu de Lanifícios: Real Fábrica de Panos. Atividades no âmbito da Arqueologia Beatriz Correia Barata / Rita Salvado

427 Arqueologia Pública e o caso da localidade da Mata (Torres Novas) Cláudia Manso / Ana Rita Ferreira / Cristiana Ferreira / Vanessa Cardoso Antunes

431 Do sítio arqueológico ao museu: um percurso (também) didático Lídia Fernandes

447 Estão todos convidados para a Festa! E para dançar também... O projecto do Serviço Educativo do Museu Arqueológico do Carmo na $5^{\underline{a}}$ Edição da Festa da Arqueologia Rita Pires dos Santos

459 O “Clã de Carenque”, um projeto didático de arqueologia Eduardo Gonzalez Rocha

469 Mediação cultural: peixe que puxa carroça nas Ruínas Romanas de Troia Inês Vaz Pinto / Ana Patrícia Magalhães / Patrícia Brum / Filipa Santos

481 Didática Arqueológica, experiências do Projeto Mértola Vila Museu Maria de Fátima Palma / Clara Rodrigues / Susana Gómez / Lígia Rafael

\section{Arte Rupestre}

497 Os inventários de arte rupestre em Portugal Mila Simões de Abreu

513 O projeto FIRST-ART - conservação, documentação e gestão das primeiras manifestações de arte rupestre no Sudoeste da Península Ibérica: as grutas do Escoural e Maltravieso Sara Garcês / Hipólito Collado / José Julio García Arranz / Luiz Oosterbeek / António Carlos Silva / Pierluigi Rosina / Hugo Gomes / Anabela Borralheiro Pereira / George Nash / Esmeralda Gomes / Nelson Almeida / Carlos Carpetudo

523 Trabalhos de documentação de arte paleolítica realizados no âmbito do projeto PalæoCôa André Tomás Santos / António Fernando Barbosa / Luís Luís / Marcelo Silvestre / Thierry Aubry

537 Imagens fantasmagóricas, silhuetas elusivas: as figuras humanas na arte do Paleolítico Superior da região do Côa Mário Reis

$55^{1}$ Os motivos zoomórficos representados nas placas de tear de Vila Nova de São Pedro (Azambuja, Portugal) Andrea Martins / César Neves / José M. Arnaud / Mariana Diniz

571 Arte Rupestre do Monte de Góios (Lanhelas, Caminha). Síntese dos resultados dos trabalhos efectuados em 2007-2009 Mário Varela Gomes

599 Gravuras rupestres de barquiformes no Monte de S. Romão, Guimarães, Noroeste de Portugal Daniela Cardoso

613 Círculos segmentados gravados na Bacia do Rio Lima (Noroeste de Portugal): contributos para o seu estudo Diogo Marinho / Ana M.S. Bettencourt / Hugo Aluai Sampaio

631 Equídeos gravados no curso inferior do Rio Mouro, Monção (NW Portugal). Análise preliminar Coutinho, L.M. / Bettencourt, A.M.S / Sampaio, Hugo A.S

645 Paletas na Arte Rupestre do Noroeste de Portugal. Inventário preliminar Bruna Sousa Afonso / Ana M. S. Bettencourt / Hugo A. Sampaio 


\section{Pré-História}

661 O projeto Miño/Minho: balanço de quatro anos de trabalhos arqueológicos Sérgio Monteiro-Rodrigues / João Pedro Cunha-Ribeiro / Eduardo Méndez-Quintas / Carlos Ferreira / Pedro Xavier / José Meireles / Alberto Gomes / Manuel Santonja / Alfredo Pérez-González

677 A ocupação paleolítica da margem esquerda do Baixo Minho: a indústria lítica do sítio de Pedreiras 2 (Monção, Portugal) e a sua integração no contexto regional Carlos Ferreira / João Pedro Cunha-Ribeiro / Sérgio Monteiro-Rodrigues / Eduardo Méndez-Quintas / Pedro Xavier / José Meireles / Alberto Gomes / Manuel Santonja / Alfredo Pérez-González

693 O sítio acheulense do Plistocénico médio da Gruta da Aroeira Joan Daura / Montserrat Sanz / Filipa Rodrigues / Pedro Souto / João Zilhão

703 As sociedades neandertais no Barlavento algarvio: modelos preditivos com recurso aos SIG

Daniela Maio

715 A utilização de quartzo durante o Paleolítico Superior no território dos vales dos rios Vouga e Côa

Cristina Gameiro / Thierry Aubry / Bárbara Costa / Sérgio Gomes / Luís Luís / Carmen Manzano / André Tomás Santos

733 Uma perspetiva diacrónica da ocupação do concheiro do Cabeço da Amoreira (Muge, Portugal) a partir da tecnologia lítica Joana Belmiro / João Cascalheira / Célia Gonçalves

745 Novos dados sobre a Pré-história Antiga no concelho de Palmela. A intervenção arqueológica no sítio do Poceirão I

Michelle Teixeira Santos

757 Problemas em torno de Datas Absolutas Pré-Históricas no Norte do Alentejo Jorge de Oliveira

771 Povoamento pré-histórico nas áreas montanhosas do NO de Portugal: o Abrigo 1 de Vale de Cerdeira Pedro Xavier / José Meireles / Carlos Alves

783 Apreciação do povoamento do Neolítico Inicial na Baixa Bacia do Douro. A Lavra I (Serra da Aboboreira) como caso de estudo Maria de Jesus Sanches

797 O Processo de Neolitização na Plataforma do Mondego: os dados do Sector C do Outeiro dos Castelos de Beijós (Carregal do Sal)

João Carlos de Senna-Martinez / José Manuel Quintã Ventura / Andreia Carvalho / Cíntia Maurício

823 Novos trabalhos na Lapa da Bugalheira (Almonda, Torres Novas) Filipa Rodrigues / Pedro Souto / Artur Ferreira / Alexandre Varanda / Luís Gomes / Helena Gomes / João Zilhão

837 A pedra polida e afeiçoada do sítio do Neolítico médio da Moita do Ourives (Benavente, Portugal)

César Neves

857 Casal do Outeiro (Encarnação, Mafra): novos contributos para o conhecimento do povoamento do Neolítico final na Península de Lisboa.

Cátia Delicado / Carlos Maneira e Costa / Marta Miranda / Ana Catarina Sousa

873 Stresse infantil, morbilidade e mortalidade no sítio arqueológico do Neolítico Final/ Calcolítico ( $4^{\circ}$ e $3^{\circ}$ milénio a.C.) do Monte do Carrascal 2 (Ferreira do Alentejo, Beja) Liliana Matias de Carvalho / Sofia N. Wasterlain 
885 Come together: O Conjunto Megalítico das Motas (Monção, Viana do Castelo) e as expressões Campaniformes do Alto Minho Ana Catarina Basílio / Rui Ramos

899 Trabalhos arqueológicos no sítio Calcolítico da Pedreira do Poio Carla Magalhães / João Muralha / Mário Reis / António Batarda Fernandes

913 O sítio arqueológico de Castanheiro do Vento. Da arquitectura do sítio à arquitectura de um território João Muralha Cardoso

925 Estudo zooarqueológico das faunas do Calcolítico final de Vila Nova de São Pedro (Azambuja, Portugal): Campanhas de 2017 e 2018 Cleia Detry / Ana Catarina Francisco / Mariana Diniz / Andrea Martins / César Neves / José Morais Arnaud

943 As faunas depositadas no Museu Arqueológico do Carmo provenientes de Vila Nova de São Pedro (Azambuja): as campanhas de 1937 a 1967 Ana Catarina Francisco / Cleia Detry / César Neves / Andrea Martins / Mariana Diniz / José Morais Arnaud

959 Análise funcional de material lítico em sílex do castro de Vila Nova de S. Pedro (Azambuja, Portugal): uma primeira abordagem Rafael Lima

971 O recinto da Folha do Ouro 1 (Serpa) no contexto dos recintos de fossos calcolíticos alentejanos

António Carlos Valera / Tiago do Pereiro / Pedro Valério / António M. Monge Soares

\section{Proto-História}

987 Produção de sal marinho na Idade do Bronze do noroeste Português. Alguns dados para uma reflexão

Ana M. S. Bettencourt / Sara Luz / Nuno Oliveira / Pedro P. Simões / Maria Isabel C. Alves / Emílio Abad-Vidal

1001 A estátua-menir do Pedrão ou de São Bartolomeu do Mar (Esposende, noroeste de Portugal) no contexto arqueológico da fachada costeira de entre os rios Neiva e Cávado Ana M. S. Bettencourt / Manuel Santos-Estévez / Pedro Pimenta Simões / Luís Gonçalves

1015 O Castro do Muro (Vandoma/Baltar, Paredes) - notas para uma biografia de ocupação da Idade do Bronze à Idade Média

Maria Antónia D. Silva / Ana M. S. Bettencourt / António Manuel S. P. Silva / Natália Félix

1031 Do Bronze Final à Idade Média - continuidades e hiatos na ocupação de Povoados em Oliveira de Azeméis João Tiago Tavares / Adriaan de Man

1041 As faunas do final da Idade do Bronze no Sul de Portugal: leituras desde o Outeiro do Circo (Beja)

Nelson J. Almeida / Íris Dias / Cleia Detry / Eduardo Porfírio / Miguel Serra

1055 A Espada do Monte das Oliveiras (Serpa) - uma arma do Bronze Pleno do Sudoeste Rui M. G. Monge Soares / Pedro Valério / Mariana Nabais / António M. Monge Soares

1065 São Julião da Branca (Albergaria-a-Velha) - Investigação e valorização de um povoado do Bronze Final

António Manuel S. P. Silva / Paulo A. P. Lemos / Sara Almeida e Silva / Edite Martins de Sá

1083 Do castro de S. João ao Mosteiro de Santa Clara: notícia de uma intervenção arqueológica, em Vila do Conde Rui Pinheiro 
1095 O castro de Ovil (Espinho), um quarto de século de investigação - resultados e questões em aberto

Jorge Fernando Salvador / António Manuel S. P. Silva

1111 O Castro de Salreu (Estarreja), um povoado proto-histórico no litoral do Entre Douro e Vouga

Sara Almeida e Silva / António Manuel S. P. Silva / Paulo A. P. Lemos / Edite Martins de Sá

1127 Castro de Nossa Senhora das Necessidades (Sernancelhe): uma primeira análise artefactual Telma Susana O. Ribeiro

${ }_{1141}$ A cividade de Bagunte. O estado atual da investigação Pedro Brochado de Almeida

1153 Zoomorfos na cerâmica da Idade do Ferro no NW Peninsular: inventário, cronologias e significado Nuno Oliveira / Cristina Seoane

1163 Vasos gregos em Portugal: diferentes maneiras de contar a história do intercâmbio cultural na Idade do Ferro

Daniela Ferreira

1175 Os exotica da necrópole da Idade do Ferro do Olival do Senhor dos Mártires (Alcácer do Sal) no seu contexto regional

Francisco B. Gomes

\section{Antiguidade Clássica e Tardia}

1191 O uso de madeira como combustível no sítio da Quinta de Crestelos (Baixo Sabor): da Idade do Ferro à Romanização Filipe Vaz / João Tereso / Sérgio Simões Pereira / José Sastre / Javier Larrazabal Galarza / Susana Cosme / José António Pereira / Israel Espi

1207 Cultivos de Época Romana no Baixo Sabor: continuidade em tempos de mudança? João Pedro Tereso / Sérgio Simões Pereira / Filipe Santos / Luís Seabra / Filipe Vaz

1221 A casa romana na Hispânia: aplicação dos modelos itálicos nas províncias ibéricas Fernanda Magalhães / Diego Machado / Manuela Martins

1235 As pinturas murais romanas da Rua General Sousa Machado, n. ${ }^{5}$ 1, Chaves José Carvalho

1243 Trás do Castelo (Vale de Mir, Pegarinhos, Alijó) - Uma exploração agrícola romana do Douro

Tony Silvino / Pedro Pereira

1255 A sequência de ocupação no quadrante sudeste de Bracara Augusta: as transformações de uma unidade doméstica Lara Fernandes / Manuela Martins

1263 Os Mosaicos com decoração geométrica e geométrico-vegetalista dos sítios arqueológicos da área do Conuentus Bracaraugustanus. Novas abordagens quanto à conservação, restauro, decoração e datação Maria de Fátima Abraços / Licínia Wrench

1277 “Casa Romana” do Castro de São Domingos (Cristelos, Lousada): Escavação, Estudo e Musealização Paulo André de P. Lemos

1291 A arqueobotânica no Castro de Guifões (Matosinhos, Noroeste de Portugal): O primeiro estudo carpológico

Luís Seabra / Andreia Arezes / Catarina Magalhães / José Varela / João Pedro Tereso 
1305 Um Horreum Augustano na Foz do Douro (Monte do Castelo de Gaia, Vila Nova de Gaia) Rui Ramos

1311 Ponderais romanos na Lusitânia: padrões, formas, materiais e contextos de utilização Diego Barrios Rodríguez

1323 Um almofariz centro-itálico na foz do Mondego

Marco Penajoia

1335 Estruturas romanas de Carnide - Lisboa Luísa Batalha / Mário Monteiro / Guilherme Cardoso

1347 O contexto funerário do sector da "necrópole NO" da Rua das Portas de S. Antão (Lisboa): o espaço, os artefactos, os indivíduos e a sua interconectividade na interpretação do passado Sílvia Loja, José Carlos Quaresma, Nelson Cabaço, Marina Lourenço, Sílvia Casimiro, Rodrigo Banha da Silva, Francisca Alves-Cardoso

${ }_{1361}$ Povoamento em época Romana na Amadora - resultados de um projeto pluridisciplinar Gisela Encarnação / Vanessa Dias

1371 A Arquitectura Residencial em Mirobriga (Santiago do Cacém): contributo a partir de um estudo de caso Filipe Sousa / Catarina Felício

${ }_{1385}$ O fim do ciclo. Saneamento e gestão de resíduos nos edifícios termais de Mirobriga (Santiago do Cacém)

Catarina Felício / Filipe Sousa

1399 Balsa, Topografia e Urbanismo de uma Cidade Portuária Vítor Silva Dias / João Pedro Bernardes / Celso Candeias / Cristina Tété Garcia

1413 No Largo das Mouras Velhas em Faro (2017): novas evidências da necrópole norte de Ossonoba e da sua ocupação medieval Ricardo Costeira da Silva / Paulo Botelho / Fernando Santos / Liliana Nunes

1429 Instrumentos de pesca recuperados numa fábrica de salga em Ossonoba (Faro) Inês Rasteiro / Ricardo Costeira da Silva / Paulo Botelho

1439 A Necrópole Romana do Eirô, Duas Igrejas (Penafiel): intervenção arqueológica de 2016 Laura Sousa / Teresa Soeiro

1457 Ritual, descarte ou afetividade? A presença de Canis lupus familiaris na Necrópole Noroeste de Olisipo (Lisboa)

Beatriz Calapez Santos / Sofia Simões Pereira / Rodrigo Banha da Silva / Sílvia Casimiro / Cleia Detry / Francisca Alves Cardoso

1467 Dinâmicas económicas em Bracara na Antiguidade Tardia Diego Machado / Manuela Martins / Fernanda Magalhães / Natália Botica

1479 Cerâmicas e Vidros da Antiguidade Tardia do Edifício sob a Igreja do Bom Jesus (Vila Nova de Gaia) Joaquim Filipe Ramos

1493 Novos contributos para a topografia histórica de Mértola no período romano e na Antiguidade Tardia Virgílio Lopes

\section{8. Época Medieval}

1511 Cerâmicas islâmicas no Garb setentrional "português": algumas evidências e incógnitas Constança dos Santos / Helena Catarino / Susana Gómez / Maria José Gonçalves / Isabel Inácio / Gonçalo Lopes / Jacinta Bugalhão / Sandra Cavaco / Jaquelina Covaneiro / Isabel Cristina Fernandes / Ana Sofia Gomes 
1525 Contributo para o conhecimento da cosmética islâmica, em Silves, durante a Idade Média Rosa Varela Gomes

1537 Yábura e o seu território - uma análise histórico-arqueológica de Évora entre os séculos VIII-XII José Rui Santos

1547 A encosta sul do Castelo de Palmela - resultados preliminares da escavação arqueológica Luís Filipe Pereira / Michelle Teixeira Santos

1559 A igreja de São Lourenço (Mouraria, Lisboa): um conjunto de silos e de cerâmica medieval islâmica

Andreia Filipa Moreira Rodrigues

1571 O registo material de movimentações populacionais no Médio Tejo, durante os séculos XII-XIII. Dois casos de "sunken featured buildings", nos concelhos de Cartaxo e Torres Novas Marco Liberato / Helena Santos / Nuno Santos

1585 O nordeste transmontano nos alvores da Idade média. Notas para reflexão Ana Maria da Costa Oliveira

1601 Sepulturas escavadas na rocha do Norte de Portugal e do Vale do Douro: primeiros resultados do Projecto SER-NPVD

Mário Jorge Barroca / César Guedes / Andreia Arezes / Ana Maria Oliveira

1619 "Portucalem Castrum Novum" entre o Mediterrâneo e o Atlântico: o estudo dos materiais cerâmicos alto-medievais do arqueossítio da rua de D. Hugo, nํ. 5 (Porto) João Luís Veloso

1627 A Alta Idade Média na fronteira de Lafões: notas preliminares sobre a Arqueologia no Concelho de Vouzela

Manuel Luís Real / Catarina Tente

1641 Um conjunto cerâmico medieval fora de portas: um breve testemunho aveirense Susana Temudo

${ }_{1651}$ Os Lóios do Porto: uma perspetiva integrada no panorama funerário da Baixa Idade Média à Época Moderna em meios urbanos em Portugal

Ana Lema Seabra

1659 O Caminho Português Interior de Santiago como eixo viário na Idade Média Pedro Azevedo

1665 Morfologia Urbana: Um exercício em torno do Castelo de Ourém André Donas-Botto / Jaqueline Pereira

1677 Intervenção arqueológica na Rua Marquês de Pombal/Largo do Espírito Santo (Bucelas, Loures)

Florbela Estêvão / Nathalie Antunes-Ferreira / Dário Ramos Neves / Inês Lisboa

1691 O Cemitério Medieval do Poço do Borratém e a espacialidade funerária na cidade de Lisboa Inês Belém / Vanessa Filipe / Vasco Noronha Vieira / Sónia Ferro / Rodrigo Banha da Silva

1705 Um Espaço Funerário Conventual do séc. XV em Lisboa: o caso do Convento de São Domingos da Cidade Sérgio Pedroso / Sílvia Casimiro / Rodrigo Banha da Silva / Francisca Alves Cardoso

\section{9. Época Moderna e Contemporânea}

1721 Arqueologia Moderna em Portugal: algumas reflexões críticas em torno da quantificação de conjuntos cerâmicos e suas inferências históricas e antropológicas Rodrigo Banha da Silva / André Bargão / Sara da Cruz Ferreira

1733 Faianças de dois contextos entre os finais do século XVI e XVIII do Palácio dos Condes de Penafiel, Lisboa

Martim Lopes / Tomás Mesquita 
1747 Um perfil de consumo do século XVIII na foz do Tejo: O caso do Mercado da Ribeira, Lisboa Sara da Cruz Ferreira / Rodrigo Banha da Silva / André Bargão

1761 Os Cachimbos dos Séculos XVII e XVIII do Palácio Mesquitela e Convento dos Inglesinhos (Lisboa)

Inês Simão / Marina Pinto / João Pimenta / Sara da Cruz Ferreira / André Bargão / Rodrigo Banha da Silva

1775 "Tomar os fumos da erua que chamão em Portugal erua sancta». Estudo de Cachimbos provenientes da Rua do Terreiro do Trigo, Lisboa

Miguel Martins de Sousa / José Pedro Henriques / Vanessa Galiza Filipe

1787 Cachimbos de Barro Caulínitico da Sé da Cidade Velha (República de Cabo Verde)

Rodrigo Banha da Silva / João Pimenta / Clementino Amaro

1801 Algumas considerações sobre espólio não cerâmico recuperado no Largo de Jesus (Lisboa) Carlos Boavida

1815 Adereços de vidro, dos séculos XVI-XVIII, procedentes do antigo Convento de Santana de Lisboa (anéis, braceletes e contas)

Joana Gonçalves / Rosa Varela Gomes / Mário Varela Gomes

1837 Da ostentação, luxo e poder à simplicidade do uso quotidiano: arqueologia e simbologia de joias e adornos da Idade Moderna Portuguesa Jéssica Iglésias

1849 Os amuletos em Portugal - dos objetos às superstições: o coral vermelho Alexandra Vieira

1865 Cerâmicas de Vila Franca de Xira nos séculos XV e XVI Eva Pires

1879 «Não passa por teu o que me pertence». Marcas de individualização associadas a faianças do Convento de Nossa Senhora de Aracoeli, Alcácer do Sal Catarina Parreira / Íris Fragoso / Miguel Martins de Sousa

1891 Cerâmica de Leiria: alguns focos de produção

Jaqueline Pereira / André Donas-Botto

1901 Os Fornos na Rua da Biquinha, em Óbidos Hugo Silva / Filipe Oliveira

1909 A casa de Pêro Fernandes, contador dos contos de D. Manuel I: o sítio arqueológico da Silha do Alferes, Seixal (século XVI) Mariana Nunes Ferreira

1921 O Alto da Vigia (Sintra) e a vigilância e defesa da costa Alexandre Gonçalves / Sandra Santos

1937 O contexto da torre sineira da Igreja de Santa Maria de Loures Paulo Calaveira / Martim Lopes

1949 A Necrópole do Hospital Militar do Castelo de São Jorge e as práticas funerárias na Lisboa de Época Moderna Susana Henriques / Liliana Matias de Carvalho / Ana Amarante / Sofia N. Wasterlain

1963 SAND - Sarilhos Grandes Entre dois Mundos: o adro da Igreja e a Paleobiologia dos ossos humanos recuperados

Paula Alves Pereira / Roger Lee Jesus / Bruno M. Magalhães

1975 Expansão urbana da vila de Cascais no século XVII e XVIII: a intervenção arqueológica na Rua da Vitória no 15 a 17

Tiago Pereira / Vanessa Filipe

1987 Novos dados para o conhecimento do Urbanismo de Faro em época Moderna Ana Rosa 
1995 Um exemplo de Arqueologia Urbana em Alcoutim: o Antigo Edifício dos CTT Marco Fernandes / Marta Dias / Alexandra Gradim / Virgílio Lopes / Susana Gómez Martínez

2007 Palácio dos Ferrazes (Rua das Flores/Rua da Vitória, Porto): a cocheira de Domingos Oliveira Maia

Francisco Raimundo

2021 As muitas vidas de um edifício urbano: História, Arqueologia e Antropologia no antigo Recreatório Paroquial de Penafiel Helena Bernardo / Jorge Sampaio / Marta Borges

2035 O convento de Nossa Senhora da Esperança de Ponta Delgada: o contributo da arqueologia para o conhecimento de um monumento identitário João Gonçalves Araújo / N’Zinga Oliveira

2047 Arqueologia na ilha do Corvo... em busca da capela de Nossa Senhora do Rosário Tânia Manuel Casimiro / José Luís Neto / Luís Borges / Pedro Parreira

2059 Perdidos à vista da Costa. Trabalhos arqueológicos subaquáticos na Barra do Tejo Jorge Freire / José Bettencourt / Augusto Salgado

2071 Arqueologia marítima em Cabo Verde: enquadramento e primeiros resultados do projecto CONCHA

José Bettencourt / Adilson Dias / Carlos Lima / Christelle Chouzenoux / Cristóvão Fonseca / Dúnia Pereira / Gonçalo Lopes / Inês Coelho / Jaylson Monteiro / José Lima / Maria Eugénia Alves / Patrícia Carvalho / Tiago Silva

2085 Trabalhos arqueológicos na Cidade Velha (Ribeira Grande de Santiago, Cabo Verde): reflexões sobre um projecto de investigação e divulgação patrimonial André Teixeira / Jaylson Monteiro / Mariana Mateus / Nireide Tavares / Cristovão Fonseca / Gonçalo C. Lopes / Joana Bento Torres / Dúnia Pereira / André Bargão / Aurélie Mayer / Bruno Zélie / Carlos Lima / Christelle Chouzenoux / Inês Henriques / Inês Pinto Coelho / José Lima / Patrícia Carvalho / Tiago Silva

2103 A antiga fortificação de Quelba / Khor Kalba (E.A.U.). Resultados de quatro campanhas de escavações, problemáticas e perspectivas futuras Rui Carita / Rosa Varela Gomes / Mário Varela Gomes / Kamyar Kamyad

2123 Colónias para homens novos: arqueologia da colonização agrária fascista no noroeste ibérico Xurxo Ayán Vila / José Mạ . Señorán Martín 


\title{
INSTRUMENTOS DE PESCA RECUPERADOS NUMA FÁBRICA DE SALGA EM OSSONOBA (FARO)
}

Inês Rasteiro ${ }^{1}$, Ricardo Costeira da Silva ${ }^{2}$, Paulo Botelho ${ }^{3}$

\begin{abstract}
RESUMO
O presente texto apresenta o estudo dos instrumentos de pesca recuperados num novo complexo de produção de preparados piscícolas identificado na zona ribeirinha de Faro (em 2017) durante uma intervenção arqueológica preventiva. À semelhança de outros espólios da mesma categoria provenientes deste tipo de officinae, a colecção é composta por anzóis, agulhas e um peso de rede.

Tendo em conta o interesse histórico e arqueológico das peças inventariadas pretendeu-se, para além da sua catalogação, realizar o estudo morfo-tipológico detalhado dos artefactos e analisar as técnicas pesqueiras utilizadas neste período cronológico, sistematizando e confrontando esta informação com a disponibilizada noutros trabalhos similares efectuados na região.

Palavras-chave: Ossonoba (Faro), Instrumentos de pesca, Anzóis, Agulhas de rede, Peso de rede em cerâmica.
\end{abstract}

\begin{abstract}
This paper addresses a group of fishing tools gathered in 2017 at an archaeological survey in a new fish production complex identified on the riverside of Faro. Like similar sets found on identical officinae, this collection is composed by hooks, needles and a clay net weight. Regarding the historic and archaeological significance of the instruments, it was intended, in addition to their catalogue and morpho-typological description, a mention of the fishing techniques used in this chronological period, confronting with the information provided by similar researches in the region.
\end{abstract}

Keywords: Ossonoba (Faro), Fishing tools, Hooks, Needles, Clay net weight.

\section{INTRODUÇÃO}

Em 2017, uma intervenção de arqueologia preventiva realizada na área ribeirinha de Faro (Portugal) permitiu identificar uma nova unidade de preparados de peixe (Figura 1 e 2), integrada numa zona de cariz industrial da antiga cidade romana de Ossonoba, da qual se conheciam escassas referências. A actividade pesqueira seria absolutamente fundamental ao funcionamento destes complexos de preparados piscícolas, recolhendo-se frequentemente neste tipo de sítios uma panóplia de materiais associados à pesca. Nesta etapa preliminar da investigação relativa ao sítio, em que se dá primazia ao estudo e divulgação da cultura material, apresenta-se a colecção de instrumentos de pesca identificada neste local composta, à semelhança de outras officinae análogas, por anzóis, agulhas e um peso de rede.

Ao contrário do que se tem vindo a observar para a vizinha província da Bética, a temática da pesca na Antiguidade e dos artefactos a ela associados não tem merecido particular atenção no actual território português. A cadência, mais ou menos regular, com que vão surgindo notícias de descoberta de novas unidades fabris conserveiras de época romana, não é acompanhada pelo acréscimo de novos estudos dedicados a este tipo de artefactos que surgem, incondicionalmente e especialmente, nesta categoria

\footnotetext{
1. Mestranda em Arqueologia. Faculdade de Letras da Universidade de Coimbra; ines.rasteiro@hotmail.com

2. Faculdade de Letras da Universidade de Coimbra; rcosteiradasilva@gmail.com

3. Engobe - Arqueologia e Património Lda.; paulo.o.botelho@gmail.com
} 
de sítios. Estes objectos só raramente são mencionados nos relatórios das intervenções e apenas excepcionalmente proporcionam estudos descritivos e tipológicos mais detalhados. Este é o caso do estudo sobre as evidências do instrumental pesqueiro de Loulé (Vargas Girón, 2017) e de dois trabalhos académicos desenvolvidos a partir do espólio recolhido no castelo de Castro Marim (Pereira, 2008) e no Monte Molião em Lagos (Lourenço, 2010). Não deixa de ser sintomático a afiliação desta temática com a região algarvia, de resto já notada nas referências bibliográficas mais antigas (Figueiredo, 1898; Ferreira, 1968; Santos, 1971-1972).

Tendo em conta a relevância das actividades piscícolas no litoral algarvio (pelo menos) desde os primeiros séculos da nossa era, interessa estudar a panóplia artefactual associada a esta actividade económica. Neste caso, as evidências expostas, sem serem excepcionais, contribuem para um melhor conhecimento das artes da pesca na Antiguidade. É neste contexto que se enquadra a singela contribuição apresentada.

\section{O CONTEXTO: A FÁBRICA DE SALGA DA R. FRANCISCO BARRETO EM FARO}

Ossonoba, localizada sob a actual capital do Algarve - Faro, terá sido uma das cidades portuárias mais importantes do sul da antiga província romana da Lusitânia. Situada na extremidade ocidental do chamado golfo de Cádis, terá desempenhado papel de relevo no tráfego mercantil entre o Mediterrâneo e o Atlântico.

Apesar do fulgor dos trabalhos de arqueologia preventiva e de emergência que nas últimas décadas se têm realizado um pouco por toda a área urbana da cidade (Viegas, 2011: 81-98) são ainda muitas as indefinições relativas ao seu traçado urbanístico e arquitectónico. Ainda assim, paulatinamente, cruzando toda a informação que vai brotando do subsolo desta urbe, é possível avançar com uma proposta de reconstituição parcial da topografia de Ossonoba (e.g. Viegas, 2011: 98, fig. 26; Bernardes, 2014: 357, lám. 2; Mantas, 2016: 41, fig. 8). A área monumental da cidade, onde se encontraria instalado o fórum (actual Largo da Sé) como centro político administrativo da capital de civitas, estaria cerzida à colina que se encontra definida pela cortina amuralhada medieval. A expansão da cidade para além dos limites do seu núcleo genético terá tido início logo na primeira metade do séc. I d.C., muito embora a consolidação e definição do seu tecido urbano tenha ocorrido apenas na segunda metade desta centúria ou já no início do séc. II (Bernardes, 2011: 13-14). Será nesta fase que a cidade ocupa a zona poente, junto à frente ribeirinha, onde irá proliferar uma intensa actividade artesanal e industrial essencialmente votada à exploração e transformação de recursos piscícolas (Bernardes, 2011: 19-20; Bernardes, 2014: 357). É neste contexto que se enquadram os vestígios postos a descoberto em 2017, na rua Francisco Barreto (Figura 1), durante intervenção arqueológica preventiva no âmbito da construção de um hotel.

A escavação, que se estendeu por cerca de $400 \mathrm{~m}^{2}$ de área, permitiu identificar duas etapas de ocupação diferenciadas. A fase de ocupação mais recente corresponde a uma unidade de preparados de peixe composta por, pelo menos, oito tanques de salga que se organizam em torno de um pátio central (Figura 2). Deste conjunto fabril, só parcialmente escavado, fazem ainda parte outros pequenos compartimentos (alguns com pavimentos em opus signinum) articulados entre si e uma área de combustão onde funcionou uma forja destinada ao trabalho do vidro. A análise preliminar do conjunto de baixela fina importada exumado nos níveis de colmatação das cetárias e de amortização da oficina permitem estimar o final da produção e consequente abandono do sítio nos finais do séc. VI (Silva \& alii, no prelo).

Todos os instrumentos de pesca recuperados e aqui dados à estampa são provenientes destes níveis, sobretudo da colmatação dos tanques de salga. Podendo eventualmente corresponder nalguns casos a material residual mais antigo, tudo indica que a generalidade da colecção se enquadre no momento precedente ao abandono do sítio.

\section{OS INSTRUMENTOS DE PESCA}

A amostra artefactual apresentada é constituída por três agulhas e dez anzóis em bronze e ainda um peso de rede em cerâmica. Neste caso, distinguem-se duas categorias de instrumentos pesqueiros: os directamente utilizados na pesca como os anzóis e o peso de rede e os que são usados complementarmente no apoio desta actividade como as agulhas. De qualquer modo, uns e outros revestem-se de igual interesse histórico e arqueológico ao atestar a prática pesqueira - uma das bases económicas desta região durante a época romana. 


\subsection{Agulhas de rede}

Entre as agulhas identificadas (Tabela 1) distinguem-se duas tipologias de acordo com a sua morfologia e função - a confecção ou a reparação de redes.

Referente à confecção das redes de pesca regista-se um exemplar completo do que vulgarmente se designa por lançadeira (Figura 3) ou agulha de "naveta” (Lourenço, 2010: 40). No fabrico da rede, a agulha passava alternadamente sob a malha, da direita para a esquerda e vice-versa (cit. por Martínez Maganto, 1992: 230). Por esse motivo, este tipo de agulhas apresenta uma morfologia e tamanho singular, assinalando-se duas partes essenciais na sua constituição, a haste e as forquilhas (Gracia Alonso, 1981-82: 324) que, por sua vez, se caracterizam por possuir diferente orientação. O exemplar, recuperado em bom estado de conservação, apresenta-se com 21,5 cm de comprimento, uma haste de secção circular com $0,35 \mathrm{~cm}$ de espessura e duas forquilhas completas (Cf. Tabela 1). Na região contam-se alguns exemplares desta tipologia, nomeadamente em Monte Molião (Lourenço, 2010: 40), Loulé Velho e Cerro da Vila (Quarteira) (Vargas Girón, 2017: 19), que exibem, no entanto, comprimento inferior $(\mathrm{c} .16 \mathrm{~cm})$ face à peça de Faro.

As restantes duas agulhas identificadas destinavam-se à reparação de redes de pesca (Cf. Tabela 1). Do ponto de vista morfológico, estes objectos são constituídos por uma haste e por uma cabeça. Um dos exemplares encontra-se bem conservado em termos de corrosão superficial embora fracturado na zona da cabeça, pelo orifício onde seria colocada a linha (Figura 4, n.․ 2). A outra agulha é mais delgada ( $0,2 \mathrm{~cm}$ de espessura) e está completa embora se encontre dobrada e com o orifício obstruído por concreções (Figura 4, n.ำ 1). Estas juntam-se a outras duas agulhas de coser já referenciadas em Faro (Santos, 1971: 196-199) e a outras peças semelhantes identificadas na região, designadamente, e uma vez mais, em Loulé Velho, Cerro da Vila (Vargas Girón, 2017:18) e Monte Molião (Lourenço, 2010: 40-41).

\subsection{Anzóis}

Os anzóis destacam-se entre os instrumentos de pesca mais comuns e facilmente identificáveis em contextos associados à actividade pesqueira. A existência de anzóis em metal é conhecida e documentada desde os alvores da metalurgia (Idade do Cobre - Calcolítico) (Ferreira, 1968: 115). Apesar disso, a sua morfologia geral não sofreu grandes alterações ao longo dos tempos. Ainda assim, uma análise tipológica mais detalhada terá de ter em conta as características das suas partes constituintes: o olhal (extremidade da haste onde se coloca a linha); a haste (que liga o olhal à curvatura do anzol); e a farpa (a extremidade afiada). Tendo em conta estes elementos pode-se ainda determinar a abertura e a garganta do anzol. A abertura corresponde à distância entre a haste e a farpa e a garganta condiz com a medida entre o extremo da abertura e a curvatura (Lourenço, 2010: 32, fig. 18).

Por suscitarem bastante interesse aquando do estabelecimento de sistemas de classificação, vários foram os investigadores que objectivaram a criação de diferentes tipologias. Neste âmbito pode mencionar-se a proposta de classificação de Déchelette (1910) que tinha por base a distinção das diferentes morfologias da extremidade distal da haste; a de Galliazzo (1979) com tipologia sustentada pela mesma variável ou, ainda, o sistema de classificação de F. Gracia Alonso (1981-1982) baseado nas variadas combinações que poderiam existir entre as diferentes partes constituintes do anzol. Em território português e ao nível do estudo morfológico e detalhado dos anzóis, deverá igualmente mencionar-se o contributo de Margarida Ribeiro (1973). Mais recentemente e no âmbito do projecto SAGENA apresenta-se uma proposta de classificação mais elaborada para os anzóis identificados no Círculo do Estreito (Bernal Casasola, 2010). A análise realizada aos dez anzóis da colecção em estudo contemplou os critérios utilizados naquele projecto, nomeadamente a morfologia, o tamanho e o sistema de fixação da linha ao anzol (Vargas Girón, 2011: 211). Os anzóis analisados são, quanto a estes preceitos, muito semelhantes, não apresentado grandes diferenças ao nível dos aspectos morfológicos ou mesmo das dimensões apresentadas (Cf. Tabela 2). Pelo que é possível observar, todos os exemplares se integram no grupo dos anzóis simples, com a extremidade da haste martelada e sem qualquer tipo de marcas ou ranhuras horizontais (Figura 5). De acordo com o estudo citado, a classificação da dimensão deste tipo de objectos baseia-se no comprimento total da haste. Também a este nível o conjunto apresenta valores muito semelhantes, integrando-se genericamente no grupo dos anzóis pequenos registando um comprimento de haste entre os 2,5 e $4 \mathrm{~cm}$.

A preponderância deste tipo de anzóis havia já sido notada nos sítios em torno do Círculo do Estreito 
(Vargas Girón, 2011: 214), sendo associados à pesca típica com cana e linha, usualmente praticada na linha de costa ou em pequenas embarcações. Apenas um exemplar da amostra (Figura 5, n..$^{-}$) apresenta um comprimento de $4,2 \mathrm{~cm}$, na fronteira que distingue os anzóis pequenos e médios. Em última análise, esta conformidade nos padrões dos anzóis poderá testemunhar uma ligação à captura das mesmas espécies piscícolas.

\subsection{Peso de rede}

Por último, refere-se a presença de uma peça de classificação controversa, mas que se optou por incluir na categoria dos pesos de rede em cerâmica. Apresenta uma forma cilíndrica e oca com estrangulamento na extremidade superior (Figura 6). Não se identificou nenhum paralelo formal absoluto. Todavia, a sua morfologia e dimensão assemelha-se aos denominados "pesos fusiformes" (Bernal Casasola, 2008: 197) identificados nalguns sítios costeiros da antiga província Mauritânia Tingitana como as fábricas de processamento de peixe em Tahaddart (na província de Tânger) (Ponsich, 1988: 149-150, fig. 32-4) ou em Septem Frates (Península de Almina, Ceuta) (Bernal Casasola, 2010: 101 e fig. 9 - CIV). A sua cronologia é para já difícil de determinar face a ausência de exemplares provenientes de contextos estratigráficos bem datados.

Caso se confirme, esta classificação acresce de interesse pois, até ao momento, a distribuição deste tipo de pesos relacionados com redes de médio ou grande porte encontrava-se limitada aos contextos pesqueiros de época imperial do litoral Tingitano, que se dispõem ao longo do Magrebe (Bernal Casasola, 2008: 197).

\section{CONSIDERAÇÕES FINAIS}

A grande densidade de vestígios de instalações conserveiras com cetárias que tem vindo continuamente a ser exposta nos sítios romanos do litoral sul da Lusitania, nomeadamente Algarve e estuários do Sado e Tejo, testemunham a vinculação dessa população ao mar e à indústria de preparados piscícolas. Neste contexto, tal como a extracção de sal, a actividade piscatória seria essencial para garantir a preparação de molhos e salgas, muito apreciados e difundidos por todo o Império Romano.

A notória evolução e diversificação das práticas pesqueiras na Antiguidade ficam a dever-se, essen- cialmente, ao desenvolvimento de um conjunto de instrumentos que tornaram a pesca uma actividade generalizada e rentável. No campo da investigação arqueológica, o estudo destes testemunhos materiais encontra-se ainda pouco desenvolvido, revelando algumas lacunas ao nível da sua perfeita contextualização e caracterização. $\mathrm{O}$ recorrente aparecimento de instrumental pesqueiro em sítios arqueológicos costeiros testemunha a ampla difusão e prática generalizada das diferentes técnicas de pesca.

Os artefactos que integram a amostra analisada remetem para o uso complementar de duas técnicas pesqueiras em particular: a pesca à linha e anzol e a utilização de redes que proporcionam capturas mais numerosas. Porém, a análise destes materiais terá de ser necessariamente correlacionada com os vestígios ictiológicos que começam, finalmente, a ser também contemplados nalguns projectos interdisciplinares. Apesar da fauna marinha surgir bem representada na iconografia (e.g. mosaicos e moedas) e referida na literatura, existem ainda algumas falhas de conhecimento relativamente às espécies capturadas e ao tipo de pesca praticada na Antiguidade. Será, provavelmente, na complementaridade entre estes dois ramos, ictiologia e o estudo do instrumental pesqueiro, que residirá a chave para o esclarecimento de algumas questões pendentes acerca desta actividade económica que seria de vital relevância para as populações costeiras, já nos primeiros séculos da nossa era.

\section{BIBLIOGRAFIA}

BERNAL CASASOLA, Darío (2008) - Arqueología de las redes de pesca. Un tema crucial de la economia marítima hispanorromana. Mainake. Málaga. XXX, pp. 181-215.

BERNAL CASASOLA, Darío (2010) - Fishing tackle in Hispania: reflections, proposals and first results. In BEKKERNIELSEN, Tonnes, BERNAL CASASOLA, Darío, eds. - Ancient nets and fishing gear: proceedings of the International Workshop on Nets and Fishing Gear in Classical Antiquity: a first approach. Cádiz, pp. 83-138.

BERNARDES, João P. (2011) - A cidade de Ossonoba e o seu território. Anais do Municipio de Faro, 37, pp.11-26.

BERNARDES, João P. (2014) - Ossonoba e o seu território: as transformações de uma cidade portuária do sul da Lusitânia. In VAQUERIZO GIL, Desiderio, GARRIGUET MATA, José A.; LEÓN MUÑOZ, Alberto, eds. - Ciudad y territorio: transformaciones materiales e ideológicas entre la época clásica y el Altomedievo, Monografías de Arqueología Cordobesa. Córdoba. 2o, pp. 355-366. 
DÉCHELETTE, Joseph (1910) - Manuale d'archéologie Prehistorique, Celtique et Gallo-Romaine, Paris.

FERREIRA, O. Veiga (1968) - Algumas notas sobre a pesca na Antiguidade. O Arqueólogo Português. Lisboa. Série III. 3, pp. 113-134.

FIGUEIREDO, António Mesquita (1898) - Contribuições para o estudo da história da pesca, em Portugal, na epocha luso-romana. O Arqueólogo Português. Lisboa. Série I. 4, pp. 53-58.

GALLIAZO, Vittorio (1979) - Bronzi romani del Museo Civico di Treviso, Roma.

GRACIA ALONSO, Francisco (1981-1982) - Ordenación tipológica del instrumental de pesca en bronce ibero-romano. Pyrenae. Barcelona. 17-18, pp. 315-328.

LOURENÇO, Pedro R. (2010) - A pesca na Antiguidade: o caso de Monte Molião (Lagos). Tese de Mestrado em Arqueologia apresentada à Faculdade de Letras da Universidade de Lisboa (disponível em http://repositorio.ul.pt/handle/ 10451/3731).

MANTAS, Vasco G. (2016) - Navegação e Portos no Algarve Romano. Al - Úlyá - Revista do Arquivo Municipal de Loulé, 16 , pp. 25-51.

MARTÍNEZ MAGANTO, Julio (1992) - Las técnicas de pesca en la Antigüedad y suimplicación económica en el abastecimiento de las industrias de salazón. Cuadernos de Prehistoria y Arqueologia de la Universidad Autónoma de Madrid. 19, pp. 219-244.

PEREIRA, Teresa R. (2008) - Os artefactos metálicos do Castelo de Castro Marim na Idade do Ferro e em época Romana - Metalurgia em transição: a amostra numa análise de conjunto. Tese de Mestrado em Arqueologia apresentada à Faculdade de Letras da Universidade de Lisboa (disponível em http://repositorio.ul.pt/handle/10451/393).

PONSICH, Michel (1988) - Aceite de oliva y salazones de pescado. Factores geo-económicos de Betica y Tingitania. Madrid: Universidad Complutense de Madrid.

RIBEIRO, Margarida (1973) - Anzóis de Tróia. Subsídios para o estudo da pesca no período lusitano-romano. O Arqueólogo Português. Lisboa. Série III. 4, pp. 221-236.

SANTOS, Maria L. E. V. (1971/1972) - Arqueologia romana do Algarve (volumes I/II). Lisboa: Associação dos Arqueólogos Portugueses.

SILVA, Ricardo C.; FERNÁNDEZ, Adolfo; SANTOS, F.; BOTELHO, P. (no prelo) - Vajillas finas importadas tardoantiguas de los niveles de abandono de la factoría de salazones de la calle Francisco barreto en Faro (Portugal). Proceedings of the $7^{\text {th }}$ International Conference on Late Roman Coarse Wares Cooking. Roman and Late Antique Mediterranean Pottery. Archaeopress: Oxford.
VARGAS GIRÓN, José M. (2011) - La pesca com caña y sedal en el Círculo del Estrecho. In BERNAL CASASOLA, Darío, ed. - Pescar con Arte. Fenícios y romanos en el origen de los aparejos andaluces. Catálogo de la exposición (Baelo Claudia, Diciembre 2011- Julio 2012). Cádiz. pp. 199-230 (Monografías del Proyecto Sagena 3).

VARGAS GIRÓN, José M. (2017) - Evidencias de instrumental pesquero en Loulé. Recientes resultados de un estudio de materiales realizado en el marco de la exposición Loulé - territórios, memórias e identidades. Al - Úlyá - Revista do Arquivo Municipal de Loulé, 18, pp. 9-24.

VIEGAS, Catarina (2011) - A ocupação romana do Algarve. Estudo do povoamento e economia do Algarve central e oriental no período romano. UNIARQ (Estudos e Memórias, 3), Lisboa. 


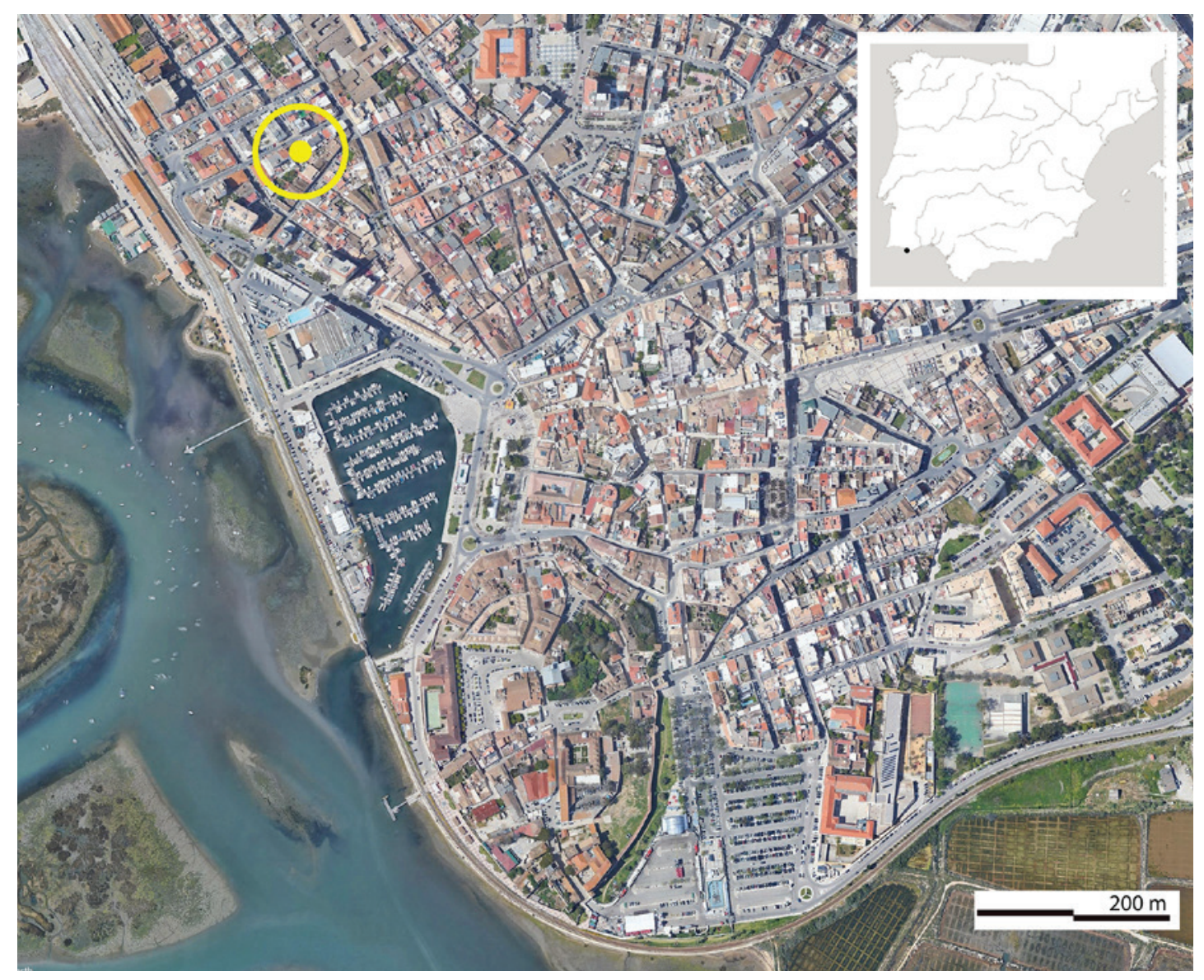

Figura 1 - Localização da intervenção na malha urbana da actual cidade de Faro (base do Google Earth).

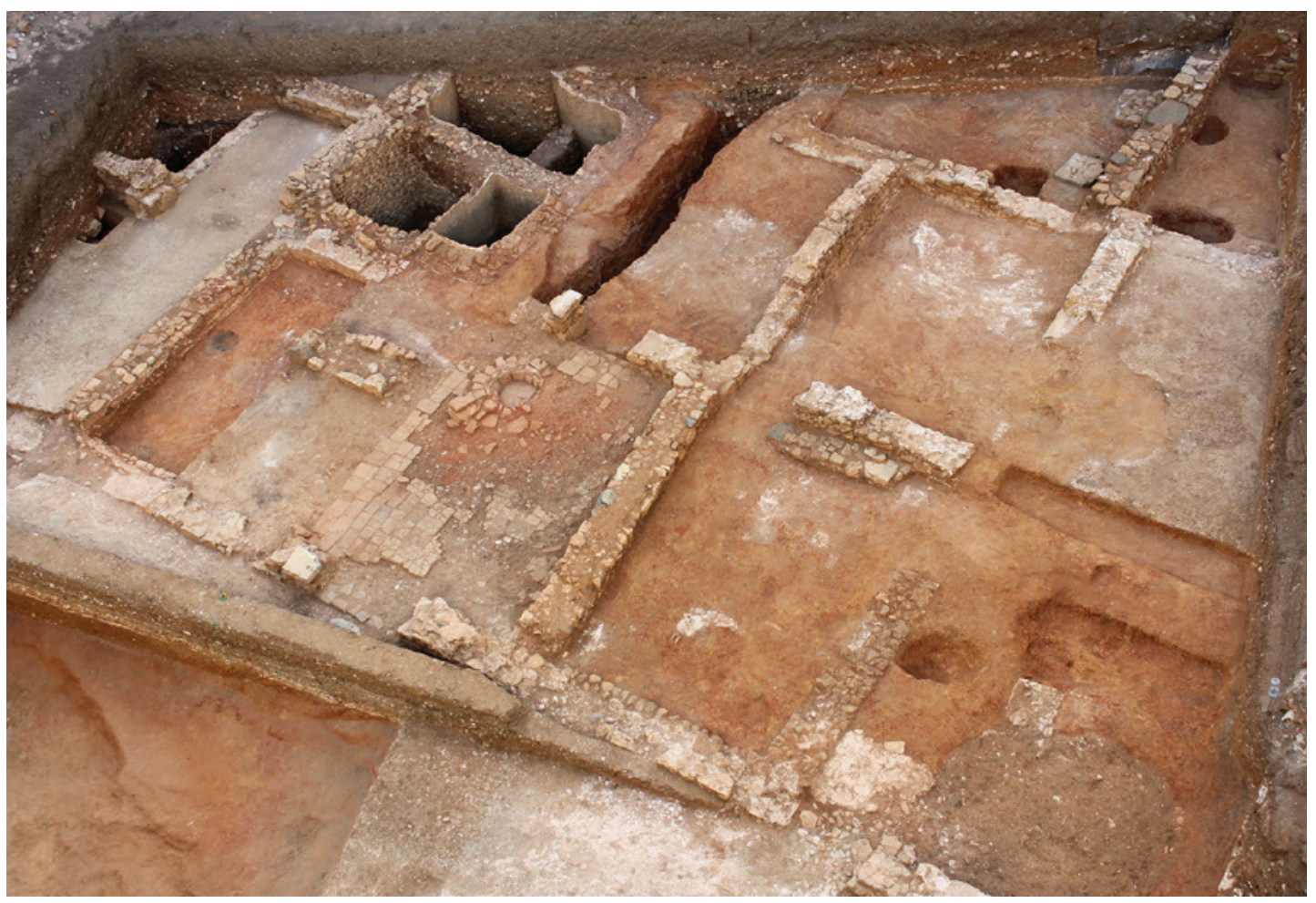

Figura 2 - Vista geral da área de intervenção. 


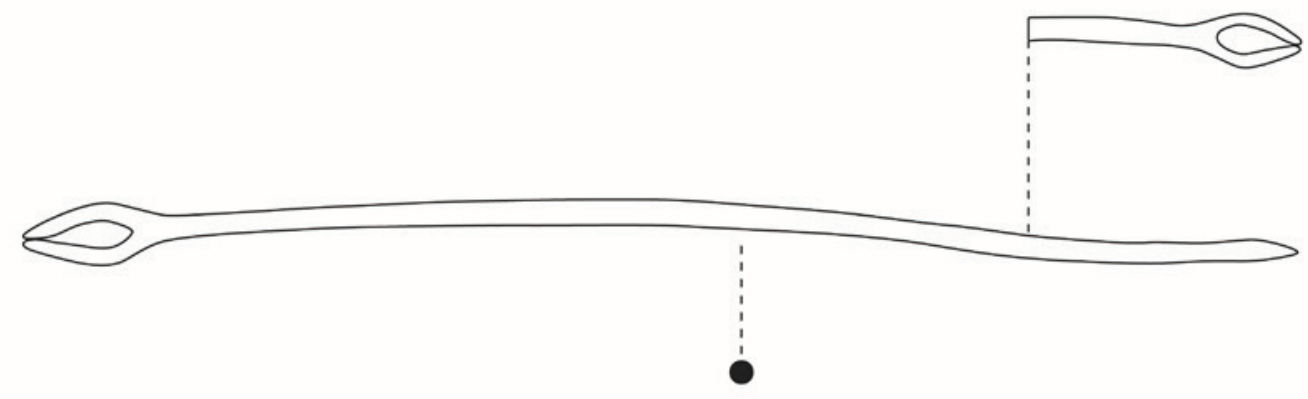

$5 \mathrm{~cm}$

Figura 3-Lançadeira.
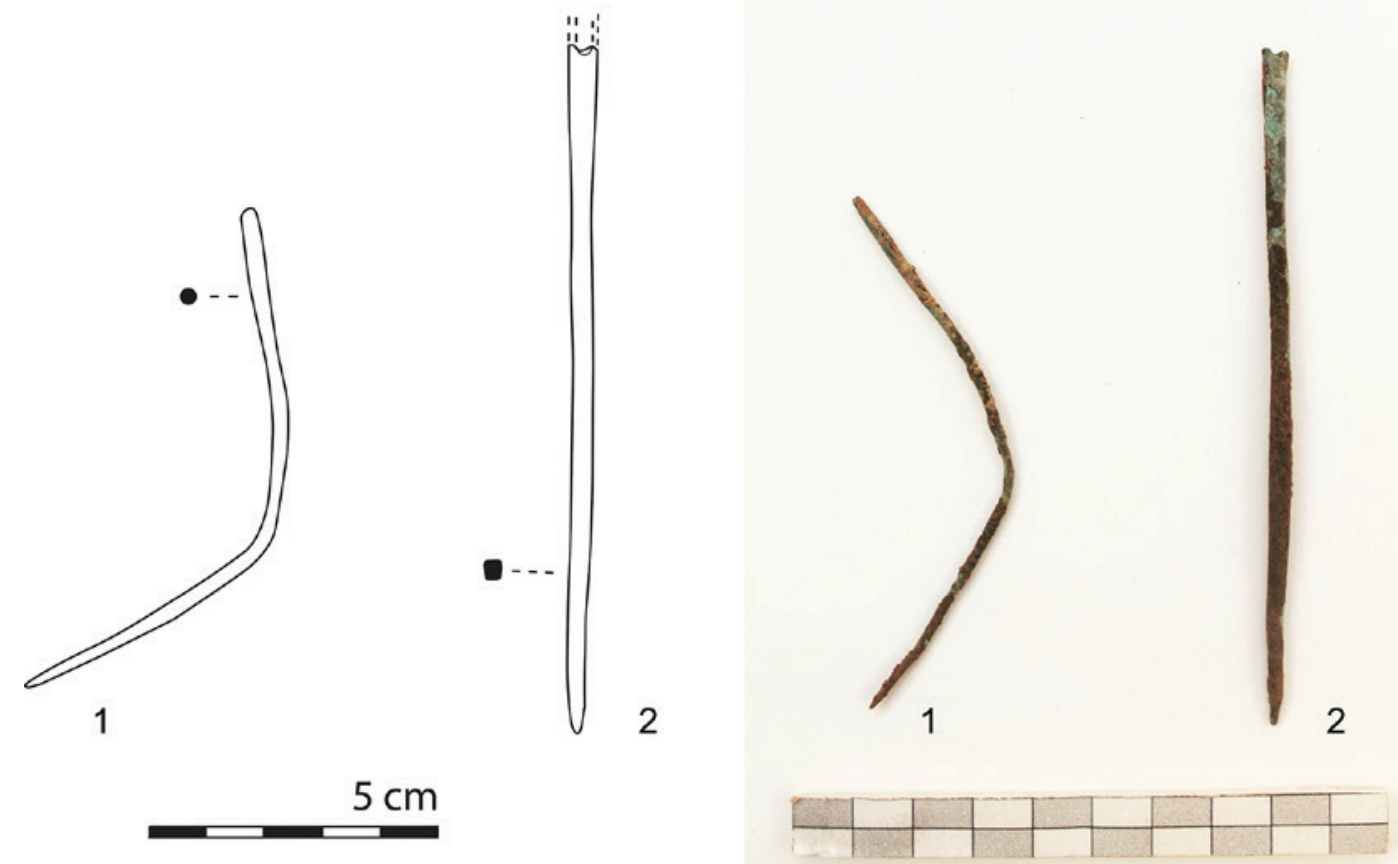

Figura 4-Agulhas. 

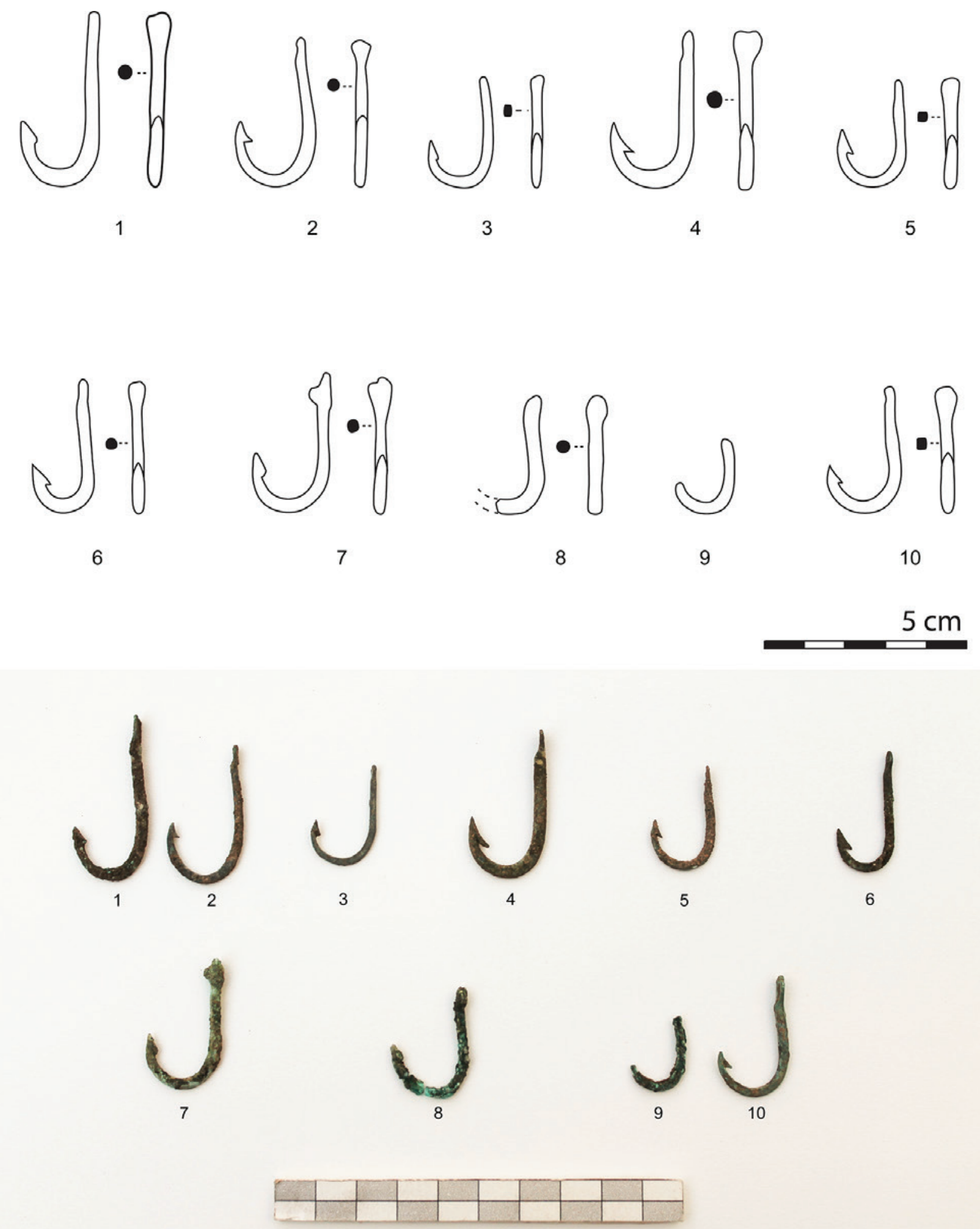

Figura 5-Anzóis. 

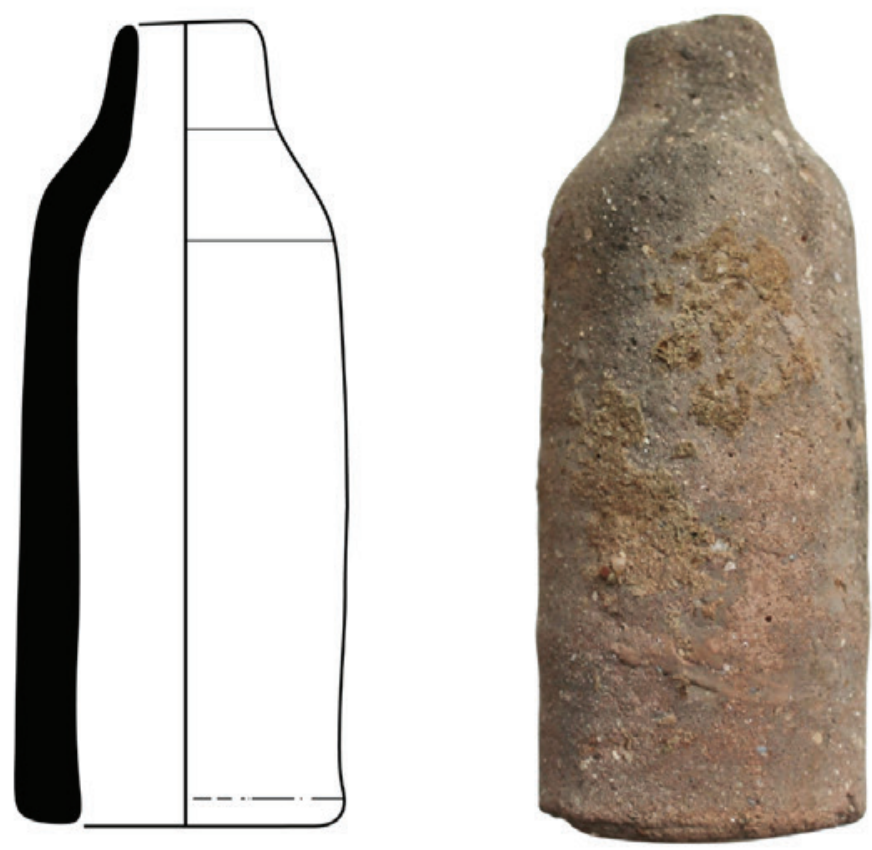

$5 \mathrm{~cm}$
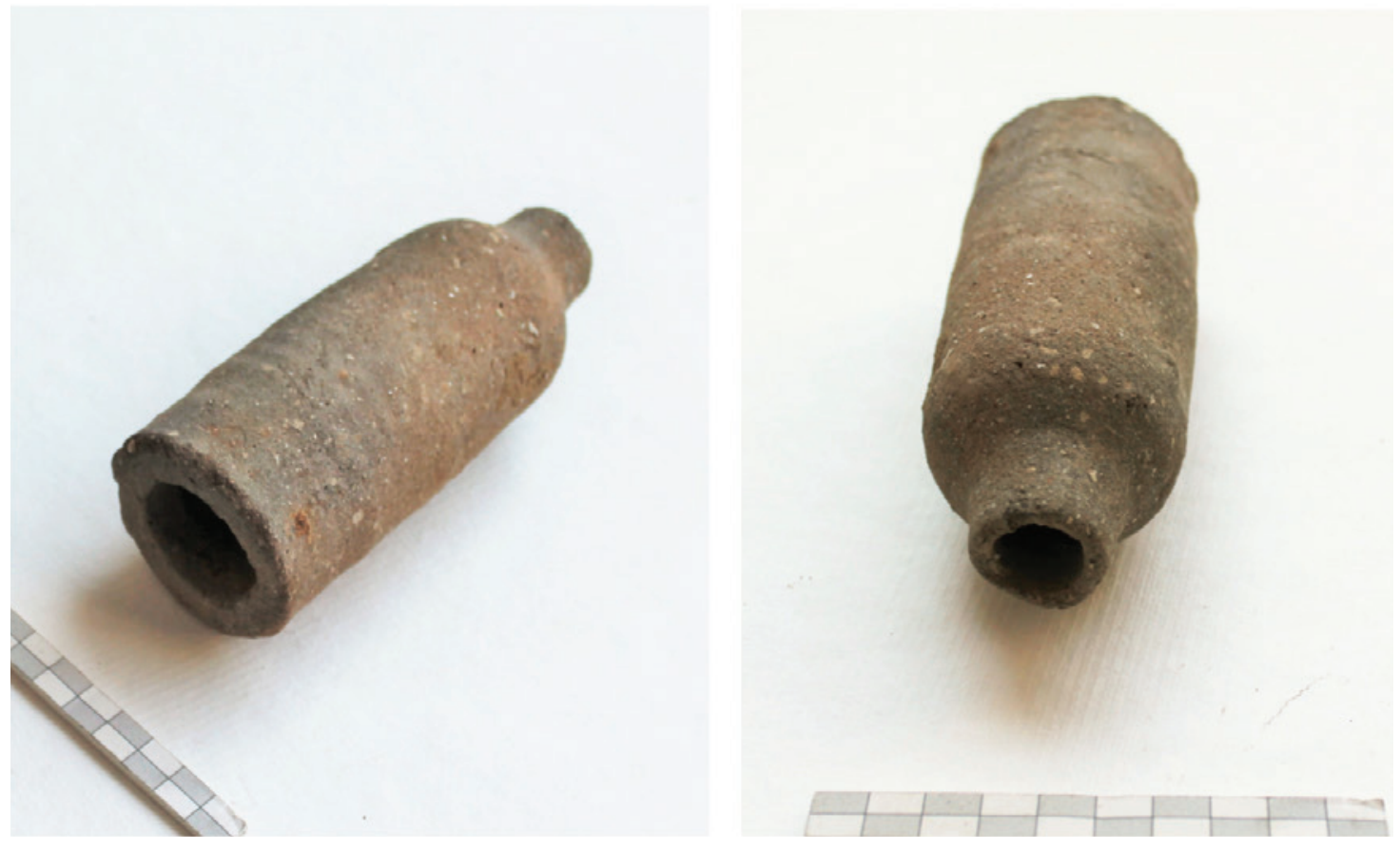

Figura 6 - Peso de rede em cerâmica. 


\begin{tabular}{|l|l|l|l|l|l|}
\hline Designação & Área e U.E. & Comprimento & Espessura & Estado de Conservação & Outras informações \\
\hline Lançadeira & Área F [707] & $21,5 \mathrm{~cm}$ & $0,35 \mathrm{~cm}$ & Completa & $\begin{array}{l}\text { Duas forquilhas, uma em } \\
\text { cada extremidade da haste; } \\
\text { Amplitude da abertura: } \\
\text { o,5x1,5cm e } 0,4 \times 1,2 \mathrm{~cm}\end{array}$ \\
\hline Agulha & Área A [719] & $11,6 \mathrm{~cm}$ & $0,5 \mathrm{~cm}$ & Incompleta & \\
\hline Agulha & Comp. V [860] & $10,2 \mathrm{~cm}$ & $0,2 \mathrm{~cm}$ & Completa, mas dobrada & \\
\hline
\end{tabular}

Tabela 1 - Agulhas - Quadro recapitulativo.

\begin{tabular}{|c|c|c|c|c|c|c|c|c|}
\hline Anzol & $\begin{array}{l}\text { Área } \\
\text { e U.E. }\end{array}$ & Comprimento & Abertura & Garganta & $\begin{array}{l}\text { Espessura } \\
\text { da haste }\end{array}$ & Farpa & $\begin{array}{l}\text { Extremidade } \\
\text { da haste }\end{array}$ & $\begin{array}{l}\text { Estado de } \\
\text { Conservação }\end{array}$ \\
\hline 1 & $\begin{array}{l}\text { Área F } \\
{[707]}\end{array}$ & $4,2 \mathrm{~cm}$ & $1,5 \mathrm{~cm}$ & $1,2 \mathrm{~cm}$ & $0,3 \mathrm{~cm}$ & Presente & Martelada & Completo \\
\hline 2 & $\begin{array}{l}\text { Área F } \\
\text { [707] }\end{array}$ & $3,6 \mathrm{~cm}$ & $1,5 \mathrm{~cm}$ & $1,4 \mathrm{~cm}$ & $0,2 \mathrm{~cm}$ & Presente & Martelada & Completo \\
\hline 3 & $\begin{array}{l}\text { Área F } \\
\text { [708] }\end{array}$ & $2,7 \mathrm{~cm}$ & $1,3 \mathrm{~cm}$ & $0,7 \mathrm{~cm}$ & $0,15 \mathrm{~cm}$ & Presente & $\begin{array}{l}\text { Subtilmente } \\
\text { martelada }\end{array}$ & Completo \\
\hline 4 & $\begin{array}{l}\text { Área A } \\
\text { [719] }\end{array}$ & $3,8 \mathrm{~cm}$ & $1,5 \mathrm{~cm}$ & $1,15 \mathrm{~cm}$ & $0,3 \mathrm{~cm}$ & Presente & Martelada & Completo \\
\hline 5 & $\begin{array}{l}\text { Área L } \\
{[865]}\end{array}$ & $2,6 \mathrm{~cm}$ & $1,3 \mathrm{~cm}$ & $1,15 \mathrm{~cm}$ & $0,2 \mathrm{~cm}$ & Presente & Martelada & Completo \\
\hline 6 & $\begin{array}{l}\text { Área D } \\
{[894]}\end{array}$ & $3,2 \mathrm{~cm}$ & $1,2 \mathrm{~cm}$ & $0,85 \mathrm{~cm}$ & $0,2 \mathrm{~cm}$ & Presente & Martelada & Completo \\
\hline 7 & $\begin{array}{l}\text { Área H } \\
\text { (Comp. } \\
\text { VIII) } \\
\text { [940] }\end{array}$ & $3,35 \mathrm{~cm}$ & $1,4 \mathrm{~cm}$ & $1,1 \mathrm{~cm}$ & $0,25 \mathrm{~cm}$ & Presente & Martelada & Completo \\
\hline 8 & $\begin{array}{l}\text { Área H } \\
\text { (Comp. } \\
\text { VIII) } \\
{[942]}\end{array}$ & $2,9 \mathrm{~cm}$ & $1,35 \mathrm{~cm}$ & $0,85 \mathrm{~cm}$ & $0,25 \mathrm{~cm}$ & $\begin{array}{l}\text { Presente } \\
\text { fragmentada }\end{array}$ & Indeterminada & Fragmentado \\
\hline 9 & $\begin{array}{l}\text { Área J } \\
\text { [967] }\end{array}$ & $1,8 \mathrm{~cm}$ & - & - & $0,25 \mathrm{~cm}$ & Ausente & Ausente & Incompleto \\
\hline 10 & $\begin{array}{l}\text { Área J } \\
\text { [967] }\end{array}$ & $3 \mathrm{~cm}$ & $1,4 \mathrm{~cm}$ & $0,85 \mathrm{~cm}$ & $0,25 \mathrm{~cm}$ & Presente & Martelada & Completo \\
\hline
\end{tabular}

Tabela 2 - Anzóis - Quadro recapitulativo. 



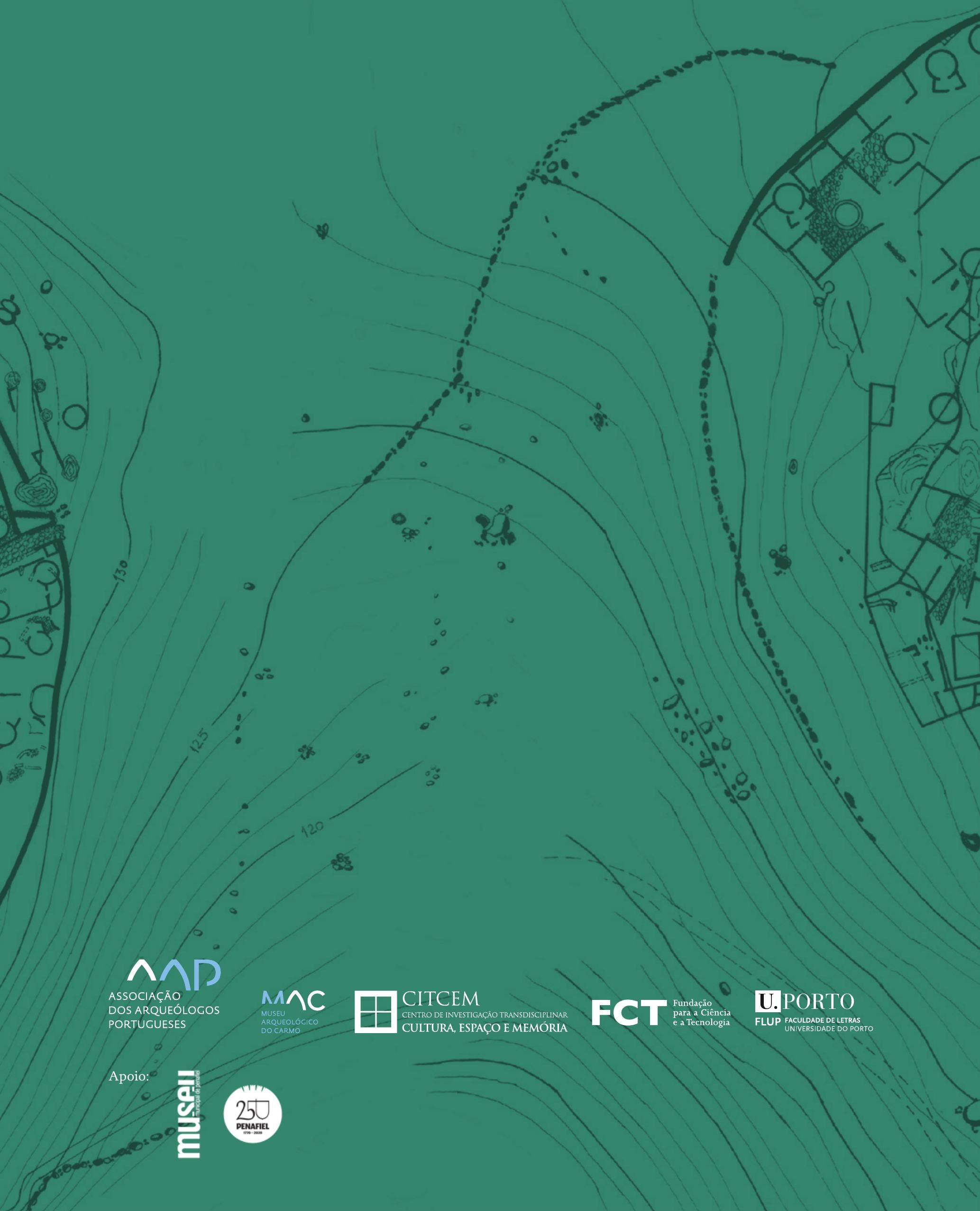

